\title{
Effect of picosecond-laser irradiation on the properties of nanostructured aluminium-doped zinc oxide thin films
}

\author{
${ }^{1}$ Khan M. N., ${ }^{1}$ Almohammedi A. and ${ }^{2}$ Farooq W. A. \\ ${ }^{1}$ Department of Physics, Faculty of Science, Islamic University, Madinah 42351, \\ Saudi Arabia mnkhan@iu.edu.sa,mnkhan_phy@yahoo.com \\ ${ }^{2}$ Department of Physics and Astron, College of Science, King Saud University, \\ Riyadh 11451, Saudi Arabia
}

Received: 20.01 .2020

\begin{abstract}
Thin films of nanostructured zinc oxide doped with aluminium of different concentrations are synthesized on glass substrates, using a spin-coated solgel method. The effect of picosecond-laser irradiation on these thin films is studied using different optical techniques. Their structural and optical properties are investigated using X-ray diffraction, near-visible and infrared absorption spectra and photoluminescence. Optical bandgap values are calculated using a Tauc's method. Slight variation in the relative intensity of X-ray diffraction and broadening of the lines are observed as a result of laser irradiation that causes some disorder in crystallinity. The relative intensities of the absorption and emission spectra decrease with increasing percentage of aluminium and laser-exposure time. The value of this decrease depends on the dopant concentration. Moreover, the emission reveals a slight red shift. The size of nanocrystals also changes at different Al doping percentages and exposure times. The reduction of the relative intensities mentioned above is attributed to changing nanocrystal sizes and structure of a surface layer.
\end{abstract}

Keywords: $\mathrm{ZnO}$ thin films, X-ray diffraction, optical absorption, bandgap, emission, laser irradiation

UDC: 535.21

\section{Introduction}

Recently transparent conducting nanostructured thin films based on oxides have obtained great attention of researchers. This is explained by their excellent plasmonic characteristics, e.g., in the near-IR frequency range. The above films have acquired many applications associated with fabricating of nano-optoelectronics devices [1,2], including displays [3, 4]. The advantages of conducting oxides lie in their transparency in the visible range, low electrical resistance and availability of such unique properties as high electron mobility, wide bandgap and strong luminescence at room temperature.

During the last decades, unique properties of transparent conducting $\mathrm{ZnO}$-based oxide have made it one of the most favourable materials for acoustic devices, optical waveguides, piezoelectric transducers, gas sensors, light emitting diodes and transparent electrodes for solar cells [5-7]. Moreover, the composite metals with $\mathrm{ZnO}$ are attractive since their useful properties can be enhanced by native defects present in their structure, while their high electrical resistivity can be reduced by doping with aluminium, boron, gallium or indium [8-11]. Among these dopants, aluminium is considered as a suitable material because of its smaller ionic radius and lower cost. When zinc oxide is doped with $\mathrm{Al}, \mathrm{Zn}$ ions are replaced by $\mathrm{Al}$ ones, thus resulting in increasing electrical conductivity. 
In order to improve the electrical and optical properties of Al-doped $\mathrm{ZnO}$ materials, several researchers have reported on $\mathrm{Al}$-doped $\mathrm{ZnO}$ thin films and powders obtained using various methods such as spray pyrolysis [12], sol-gel [13], precipitation [14], and hydrothermal processes [15]. Our group has also studied nanocrystalline Al-doped $\mathrm{ZnO}$ which reveals a blue shift in bandgap and an UV emission related mainly to the carrier concentration changes induced by Aldonor doping [16]. A degree of crystalline order has also been investigated.

Notice that irradiation with laser sources has proved to be a powerful tool for transforming both the surface and bulk physical properties of many functional materials [17, 18]. The laser irradiation technique has some advantages over the classic annealing method. Indeed, then the thermal exposure is less, the heating is local, whereas the effect of substrate temperature is reduced and becomes easily manageable [19]. Notable influence of laser irradiation have been demonstrated for different parameters, e.g. for the optical bandgap [20, 21] and the photoluminescence (PL) [22-25] of undoped nanostructured $\mathrm{ZnO}$ films. Improvement in the electrical conductivity of high-quality $\mathrm{n}$-type $\mathrm{ZnO}$ has been observed after laser irradiation [26, 27]. In spite of these successes, a limited number of works have dealt with the effect of laser irradiation on the properties of Al-doped $\mathrm{ZnO}$ films. Only very recently, electrical properties, surface morphology, optical transmission and gas-sensing features have been studied in a number of works [28-30]. In particular, a decrease in the resistivity and the optical bandgap has been observed for the Al-doped $\mathrm{ZnO}$ films.

$\mathrm{Up}$ to date, a few reports on the electrical properties of Al-doped $\mathrm{ZnO}$ thin films affected by laser irradiation are known from the literature. To our best knowledge, the effect of high-power picosecond laser irradiation on the optical, structural and PL properties of nanostructured Al-doped $\mathrm{ZnO}$ thin films have still not been investigated. The only exception is the study by F. L. Tang and his group [31] on the optical properties of Al-doped $\mathrm{ZnO}$ films modified by laser irradiation. In the present work, we have used a high-power picosecond laser working at $355 \mathrm{~nm}$ to irradiate Aldoped $\mathrm{ZnO}$ thin films under conditions of different exposure times. In this manner, we study the effect of picosecond-laser radiation on various properties of these films.

\section{Material and methods}

\subsection{Preparation}

$\mathrm{ZnO}$ solution was prepared by dissolving zinc acetate dehydrate $\left[\mathrm{ZnAc}:\left(\mathrm{Zn}\left(\mathrm{CH}_{3} \mathrm{COO}\right)_{2} 2 \mathrm{H}_{2} \mathrm{O}\right)\right]$ in 2-propanol and diethanolamine $\mathrm{C}_{4} \mathrm{H}_{11} \mathrm{NO}_{2}$. Initially, $\mathrm{ZnAc}$ was dissolved in 2-propanol and then diethanolamine was added to increase solubility. The unit molar ratio of diethanolamine/ZnAc was taken, which corresponded to solution with the concentration $0.5 \mathrm{M}$. Besides of the precursor solution of Al-doped $\mathrm{ZnO}$, aluminium acetate basic hydrate $\left[\left(\mathrm{CH}_{3} \mathrm{CO}_{2}\right) \mathrm{AlOHH} \mathrm{H}_{2} \mathrm{O}\right]$ was used as a doping agent. We obtained $\mathrm{Al}$-doped $\mathrm{ZnO}$ thin films with different $\mathrm{Al}$ concentrations. To be more specific, we chose the following molar $\mathrm{Al} / \mathrm{Zn}$ ratios: $\mathrm{Al}^{+3} / \mathrm{Zn}^{+2}=0.1,0.2,0.5$ and 1.0 at. wt. $\%$. This was done by adding aluminium acetate basic hydrate to the precursor solution used to synthesize $\mathrm{ZnO}$. The final precursor solutions were stirred at $70^{\circ} \mathrm{C}$ for $2 \mathrm{~h}$ to yield a clear and homogenous solution. The glass substrates with the dimensions $10 \times 10 \mathrm{~mm}^{2}$ were cut and cleaned in ethanol for $10 \mathrm{~min}$, using an ultrasonic cleaner. Then they were cleaned using deionized water and dried. A gel solution was deposited onto a glass substrate at $3000 \mathrm{rpm}$ for $30 \mathrm{~s}$, using a spin coater Laurell EDC-650-23B. After deposition by spin coating, the films were preheated at $250^{\circ} \mathrm{C}$ for $10 \mathrm{~min}$ on a hot plate to evaporate the solvent and remove organic residuals. Finally, the films were annealed at $400^{\circ} \mathrm{C}$ for $2 \mathrm{~h}$.

Ukr. J. Phys. Opt. 2020, Volume 21, Issue 3 


\subsection{Characterizations}

Our thin-film samples were irradiated using a $355 \mathrm{~nm}$ laser beam from a mode-locked and Q-switched Nd:YAG Picosecond Tunable Laser System LS-2151 (LOTTIS II, Belarus). The wavelength $355 \mathrm{~nm}$ was generated as a third harmonic from the fundamental $1064 \mathrm{~nm}$ wavelength. The pulse duration of the fundamental beam was equal to $70-80 \mathrm{ps}$ and the pulsed repetition rate of the laser was $15 \mathrm{~Hz}$. The maximum output pulse energy at $355 \mathrm{~nm}$ was $21 \mathrm{~mJ}$ (at $15 \mathrm{~Hz}$ ). The output pump energy used to irradiate the samples was equal to $6 \mathrm{~mJ}$ per pulse. The sample was placed in front of unfocussed beam. All the other parameters were kept constant except for the number of pulses. The exposure area of the sample and the energy of the laser were fixed and kept constant during the laser irradiation procedure. In our experiments, the exposure time (i.e., the number of pulses) was increased to examine the effect of the laser light. The laser beam diameter was $6 \mathrm{~mm}$. It overlapped all the samples and the positions of all those samples were fixed. Moreover, the laser beam was incident at the exposed sample area. In our experiments, very short laser pulses with low energies were used, which were kept below ablation threshold. Only the peak power of laser was varied.

The absorption, emission and IR absorption spectra of the samples before and after laser irradiation were recorded using an UV-visible-near-IR spectrophotometer Model 670 (JASCO), a Lumina Fluorescence Spectrophotometer (Thermo Scientific) and a Fourier-transform IR spectrometer (Perkin Elmer), respectively. X-ray diffraction (XRD) images of nanostructured $\mathrm{ZnO}$ and $\mathrm{Al}$-doped $\mathrm{ZnO}$ films were examined using an XRD equipment PANalytical X'Pert with $\mathrm{Cu}-\mathrm{K}_{\alpha}$ radiation $(\lambda=0.154 \mathrm{~nm})$, which was operated at $45 \mathrm{kV}$ and $40 \mathrm{~mA}$. The surface morphology of Aldoped $\mathrm{ZnO}$ films before and after laser irradiation was studied with a field-emission scanning electron microscope.

\section{Results and discussion \\ 3.1. $X$-ray experiments}

The structures of Al-doped $\mathrm{ZnO}$ thin films before and after irradiation have been studied through the XRD experiments. The XRD patterns observed for the pure $\mathrm{ZnO}$ films and the doped films with 0.1, $0.2,0.5$ and $1.0 \%$ of $\mathrm{Al}$ are shown in Fig. 1 under conditions of different exposure times $(1,2$ and $3 \mathrm{~min}$ ). The XRD patterns reveal that the crystalline structure of both pure $\mathrm{ZnO}$ and nanostructured Al-doped $\mathrm{ZnO}$ thin films is polycrystalline, and the structure belongs to a hexagonal wurtzite type [32]. No crystalline phases of any other oxides and no substantial changes in the XRD peaks are observed, as compared to the standard wurtzite-like patterns. The only exception is slight variations in the relative intensities and broadening of the lines. These variations are due to slight modification of the shape and the size of nanocrystals because of the presence of doping $\mathrm{Al}$ ions and interaction of matter with the laser radiation. A small shift in the peak positions towards larger Bragg angles due to $\mathrm{Al}$ doping and laser irradiation is also evident. The shift associated with the laser irradiation is larger that that related to the doping. This might be due to residual stresses caused by different ionic radii of $\mathrm{Zn}^{2+}$ and incorporated $\mathrm{Al}^{3+}$ ions [33]. A decrease in the peak intensities taking place with increasing laser irradiation can be attributed to increasing disorder in crystallinity.

The nanocrystal sizes have been determined from the full width at half maximum in the diffraction plane (002), using the Scherrer's equation and taking into account the highest intensity peak for the pure and $\mathrm{Al}$-doped $\mathrm{ZnO}$ thin films at different irradiation times [16]. The crystal size $t$ is then determined as

$$
t=\frac{k \lambda}{\beta \cos \theta},
$$

where $\lambda$ is the $\mathrm{X}$-ray wavelength $(0.15406 \mathrm{~nm}), \beta$ the full width at half maximum for $\mathrm{ZnO}, \theta$ the 
Bragg angle, and $k$ a constant. Thus predicted sizes before and after laser irradiation are listed in Table 1. The shorter irradiation time (i.e., 1 and $2 \mathrm{~min}$ ) are not mentioned there, since they result in no significant effect on the peaks.
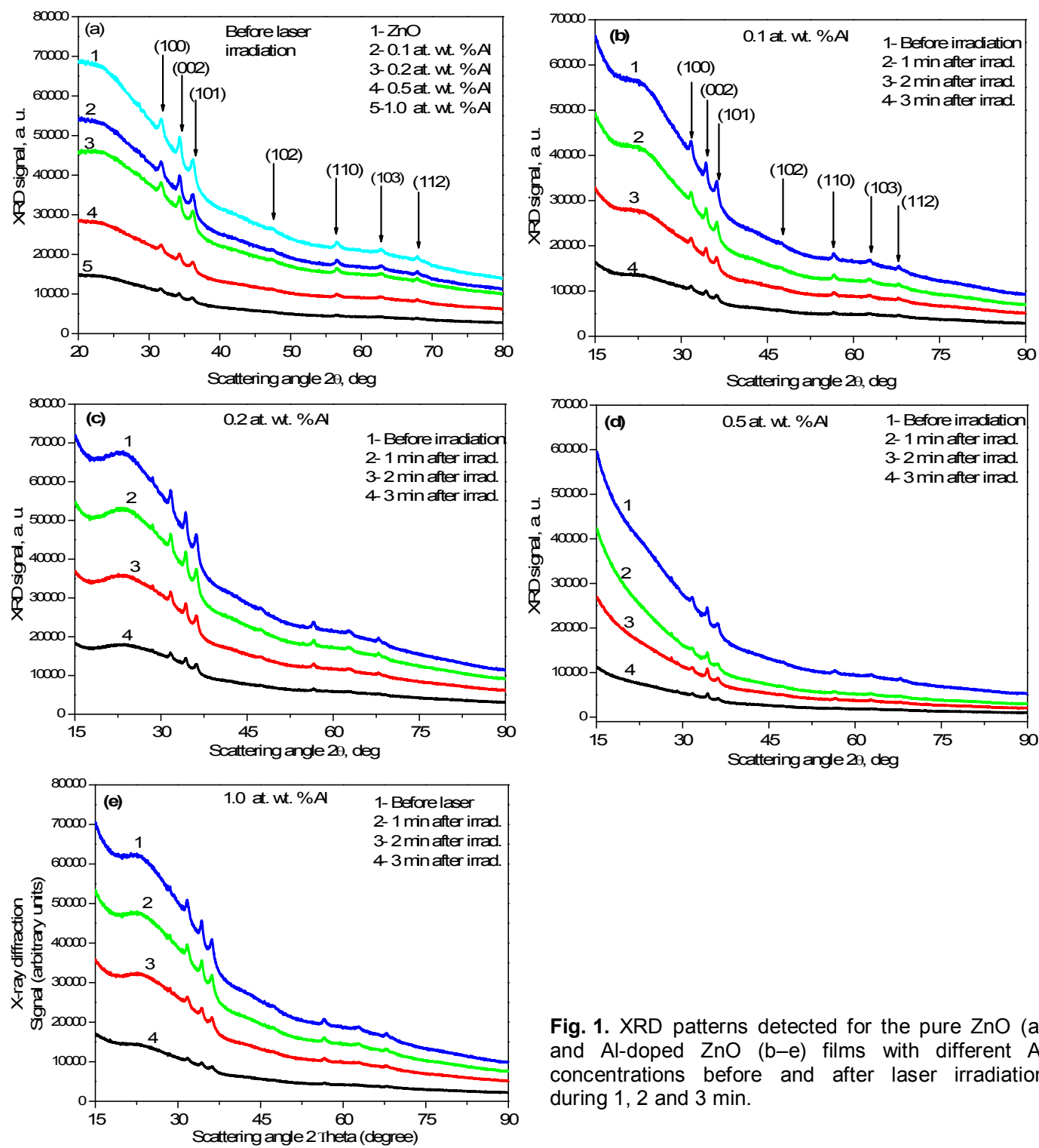

Fig. 1. XRD patterns detected for the pure $\mathrm{ZnO}$ (a) and Al-doped $\mathrm{ZnO}(\mathrm{b}-\mathrm{e})$ films with different $\mathrm{Al}$ concentrations before and after laser irradiation during 1,2 and 3 min.

Table 1. Crystal sizes calculated for the pure $\mathrm{ZnO}$ and $\mathrm{Al}$-doped $\mathrm{ZnO}$ thin films before and after 3 min-long laser irradiation.

\begin{tabular}{cccccc}
\hline Sample(thin film) & $\begin{array}{c}\text { Pure nano- } \\
\text { structured } \mathrm{ZnO}\end{array}$ & $\begin{array}{c}\text { Al-doped } \\
\mathrm{ZnO}\end{array}$ & $\begin{array}{c}\text { Al-doped } \\
\mathrm{ZnO}\end{array}$ & $\begin{array}{c}\text { Al-doped } \\
\mathrm{ZnO}\end{array}$ & $\begin{array}{c}\text { Al-doped } \\
\text { ZnO }\end{array}$ \\
\hline $\begin{array}{c}\text { Al percentage } \\
\text { Crystalline size before } \\
\text { laser irradiation, nm }\end{array}$ & 0.0 & 0.1 & 0.2 & 0.5 & 1 \\
$\begin{array}{l}\text { Crystalline size after } \\
\text { laser irradiation, nm }\end{array}$ & 12.29 & 11.24 & 12.45 & 11.01 & 7.78 \\
\hline
\end{tabular}

Ukr. J. Phys. Opt. 2020, Volume 21, Issue 3 
The calculated values listed in Table 1 confirm a nanostructured character of our samples. It can be seen that the nonocrystal sizes differ for different percentages of $\mathrm{Al}$ and for different exposure times. The sizes decrease with increasing Al doping because of different ionic radii of the host and dopant ions. Under laser irradiation, the grain size decreases at low Al doping but increases at increased $\mathrm{Al}$ doping levels. The latter increase might be due to rapid cooling rate after irradiation. At longer laser exposure times, the samples can heat notably and then the temperature drops rapidly to the room temperature. Then the rapid cooling can induce local non-uniform tensile stresses which, eventually, can enlarge the grain size [34].

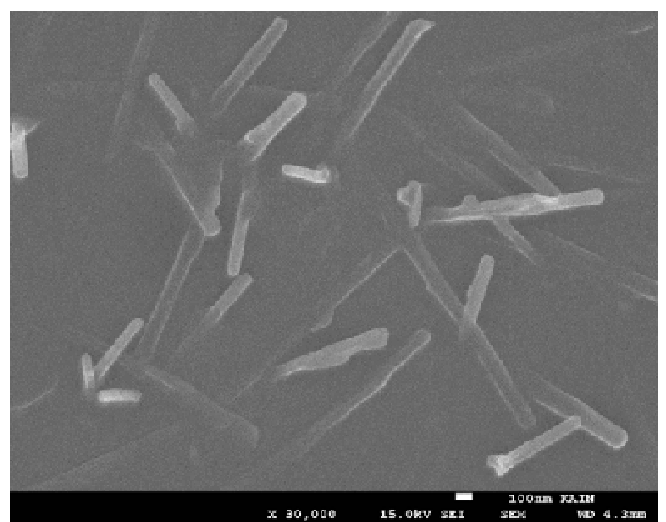

(a)

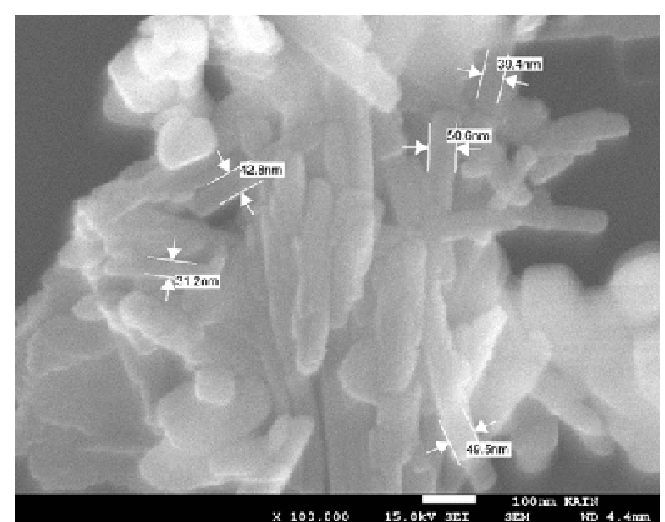

(b)

Fig. 2. Field-emission scanning electron microscope images obtained for $1.0 \% \mathrm{Al}$-doped $\mathrm{ZnO}$ before (a) and after (b) 3 min-long laser irradiation.

Surface morphology of the Al-doped $\mathrm{ZnO}$ films before and after laser irradiation has been studied with the field-emission scanning electron microscope. The appropriate images are shown in Fig. 2 . The surface of the $\mathrm{Al}$-doped $\mathrm{ZnO}$ film before the laser treatment reveals $\mathrm{ZnO}$ nanorods covered with $\mathrm{Al}$ surface layer. A dense distribution of $\mathrm{ZnO}$ nanorods on $\mathrm{Al}$ surface can be observed before irradiation. After the laser treatment, the surface layer of $\mathrm{ZnO}$ nanorods is remarkably changed. Namely, a majority of nanorods become overlapped and loosely bound with Al. This indicates that the laser energy can penetrate and deform the surface of Al-doped $\mathrm{ZnO}$ films, thus leading to overlapped nanorods (see Fig. 2b). When the laser light interacts with the surface of Al-doped $\mathrm{ZnO}$, the laser energy could impose defects in $\mathrm{Al}$ layer and $\mathrm{ZnO}$ nanorods. The aggregate of $\mathrm{ZnO}$ rods with $\mathrm{Al}$ occurring after laser irradiation can cause increase in their effective size, which is observed by the XRD. A similar result has been observed when the laser energy increases. Then the particle size increases, too [31].

\subsection{Optical absorption}

The optical absorption spectra in the visible range for the pure and Al-doped $\mathrm{ZnO}$ thin films as functions of $\mathrm{Al}$ concentration are shown in Fig. 3a. Here the data concerns the state before laser irradiation. The same absorption spectra referred to different laser exposure times are displayed in Fig. 3b-e. In each figure, the absorbance dependences of the light wavelength are presented. The absorption peak for the pure $\mathrm{ZnO}$ film appears around $365 \mathrm{~nm}$. This peak is slightly changed when $\mathrm{Al}$ is present. The absorbance of $\mathrm{ZnO}$ decreases with increasing percentage of $\mathrm{Al}$ doping. Moreover, the value of this decrease varies for different doping concentrations. The absorption peak manifests a slight blue shift with increasing Al percentage. The detailed data for the absorption peaks is listed in Table 2. When the Al-doped $\mathrm{ZnO}$ thin films are irradiated, the absorbance decreases with increasing $\mathrm{Al}$ doping and exposure time. The decreases in the absorbance occurring 

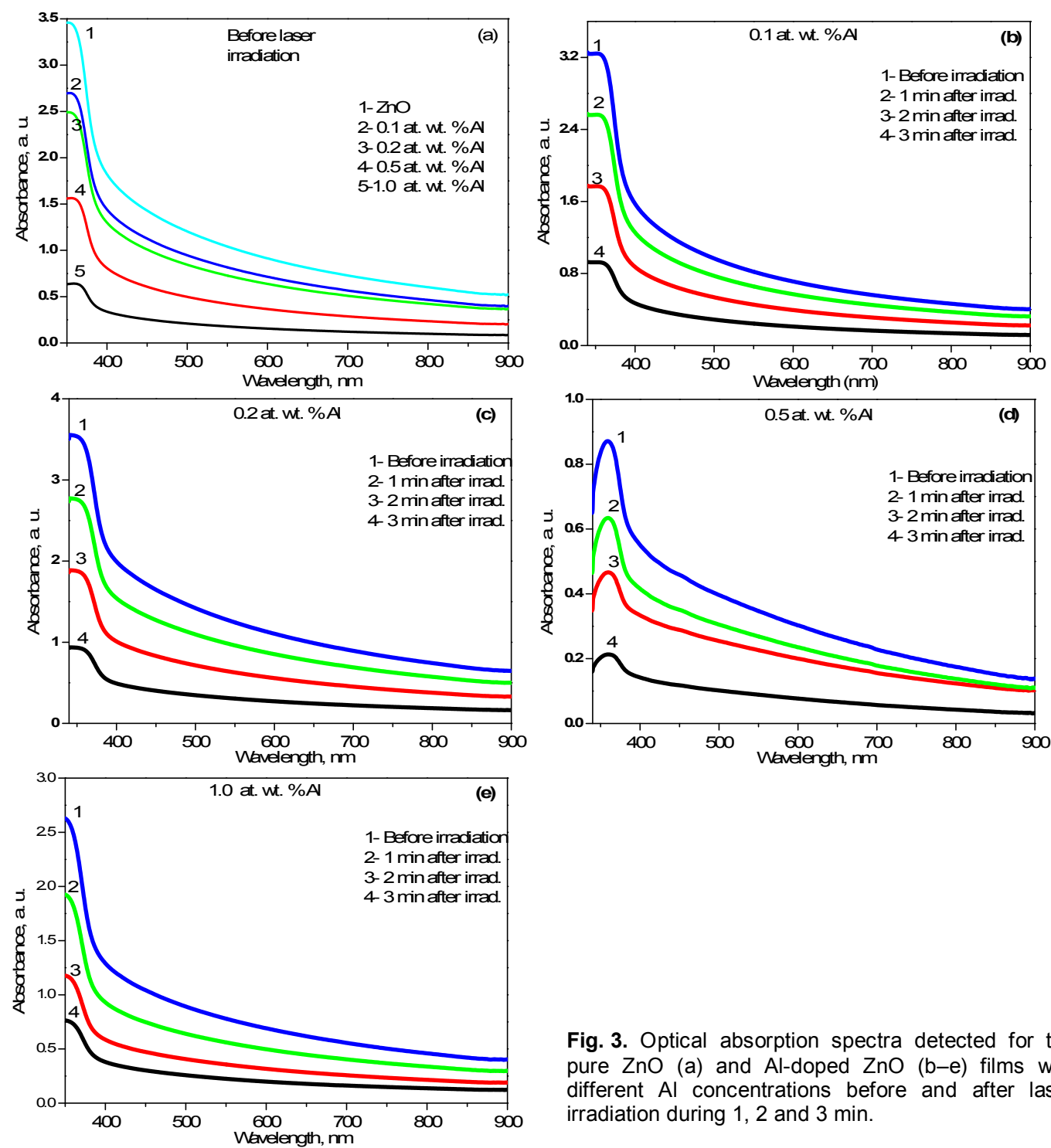

Fig. 3. Optical absorption spectra detected for the pure $\mathrm{ZnO}$ (a) and Al-doped $\mathrm{ZnO}$ (b-e) films with different $\mathrm{Al}$ concentrations before and after laser irradiation during 1, 2 and 3 min.

Table 2. Optical absorption peaks for the pure $\mathrm{ZnO}$ and $\mathrm{Al}$-doped $\mathrm{ZnO}$ thin films detected before and after 3 min-long laser irradiation.

\begin{tabular}{lccccc}
\hline \multicolumn{1}{c}{ Sample (thin film) } & $\begin{array}{c}\text { Pure nano- } \\
\text { structured } \mathrm{ZnO}\end{array}$ & $\begin{array}{c}\text { Al-doped } \\
\mathrm{ZnO}\end{array}$ & $\begin{array}{c}\text { Al-doped } \\
\mathrm{ZnO}\end{array}$ & $\begin{array}{c}\text { Al-doped } \\
\text { ZnO }\end{array}$ & $\begin{array}{c}\text { Al-doped } \\
\text { ZnO }\end{array}$ \\
\hline Al percentage & 0.0 & 0.1 & 0.2 & 0.5 & 1 \\
$\begin{array}{l}\text { Absorption peak before } \\
\text { laser irradiation, nm }\end{array}$ & 365 & 359 & 348 & 361 & 359 \\
$\begin{array}{l}\text { Absorption peak after } \\
\text { laser irradiation, } \mathrm{nm}\end{array}$ & 359 & 356 & 357 & 358 & 356 \\
\hline
\end{tabular}

with increasing Al doping is due to induction of crystal defects and free charge carriers [34, 35]. Under laser irradiation of films, the decrease is different for different Al doping levels. A slight blue shift in the absorption peak is also observed (see Fig. 3b-e). This can be a reason of the fact that the transmission of the film is decreased remarkably when the Al percentage increases. It is 
worth mentioning that the Al-doped $\mathrm{ZnO}$ thin films have weaker crystallization, which is attributed to optical scattering at the grain boundaries [36, 37].

We have studied the absorption coefficient and the bandgap for the pure and $\mathrm{Al}$-doped $\mathrm{ZnO}$ thin films as functions of $\mathrm{Al}$ concentration and laser exposure time, following Ref. [16]. The optical bandgap for the Al-doped $\mathrm{ZnO}$ thin films can be calculated using a known Tauc's relation:

$$
(\alpha h v)^{\frac{1}{n}}=A\left(h v-E_{g}\right),
$$

where $\alpha$ denotes the absorption coefficient, $h v$ the photon energy and $A$ some constant. Here $E_{g}$ is the optical bandgap of the material and the exponent $n$ depends on the nature of optical transition. For instance, the $n$ value is taken to be $1 / 2$ in the case of direct optical bandgap. $n$ can be determined from the $(\alpha h v)^{2}$ vs. $h v$ plot by extrapolating linear part of the plot towards the abscissa axis (i.e., the photon energy $h v$ ). The intercept of extrapolated part of the linear dependence with the $h v$ axis gives the direct bandgap [36, 37]. The linear part of the $(\alpha h v)^{2}$ curve is extrapolated towards the energy $h v$ axis at $(\alpha h v)=0$, as shown in Fig. 4 .

The absorption coefficient of $\mathrm{ZnO}$ increases after addition of $\mathrm{Al}$ or after laser treatment. The bandgap values for pure $\mathrm{ZnO}$ and for different $\mathrm{Al}$-doped $\mathrm{ZnO}$ thin films measured before and after 3 min-long laser exposure are listed in Table 3. Fig. 4 and Table 3 reveal that the bandgap value for pure $\mathrm{ZnO}$ amounts to $3.76 \mathrm{eV}$. This indicates the existence of nanostructure in the thin film. It can also be noted that there is some variation in the optical bandgap with changing $\mathrm{Al}$ doping level and laser exposure time.

Fig. 4a illustrates the calculations of optical bandgap values for the pure and $\mathrm{Al}$-doped $\mathrm{ZnO}$ thin films. The bandgap increases with increasing Al percentage. The increase in the direct bandgap can be attributed to the Moss-Burstein effect [38]. This effect causes the energy band to widen (blue shift), which arises from elevated Fermi level at lower doping levels. The Moss-Burstein effect happens when there is an increase in the carrier concentration. This lifts the Fermi level into the conduction band and leads to increase in the optical bandgap [39]. Our group has demonstrated [16] that the blue shift in the energy bandgap of Al-doped $\mathrm{ZnO}$ is related to the carrier concentration changes induced by Al-donor doping and to the less degree of crystalline order. A similar result has earlier been reported by Maeng et al. [40]. They have observed that the absorption edge is blueshifted from $3.19 \mathrm{eV}$ (for pure $\mathrm{ZnO}$ ) to $3.26 \mathrm{eV}$ (for Al-doped $\mathrm{ZnO}$ with the $\mathrm{Al}$ concentration $3 \%$ ). A lower bandgap value observed in this work has been assumed to be a consequence of native point defects such as oxygen vacancies and zinc interstitials. Furthermore, the increase in the optical bandgap that occurs with increasing $\mathrm{Al}$ concentration has been considered as a result of availability of $\mathrm{Al}$ ions that tend to occupy positions inside $\mathrm{ZnO}$ lattice planes. The latter causes a transport path for charge carriers into $\mathrm{ZnO}$ lattice, which is confirmed by the electrical measurements [41].

Table 3. Optical bandgap values detected for the pure $\mathrm{ZnO}$ and $\mathrm{Al}$-doped $\mathrm{ZnO}$ thin films before and after 3 min-long laser irradiation.

\begin{tabular}{lccccc}
\hline Sample (thin film) & $\begin{array}{c}\text { Pure nano- } \\
\text { structured } \mathrm{ZnO}\end{array}$ & $\begin{array}{c}\text { Al-doped } \\
\mathrm{ZnO}\end{array}$ & $\begin{array}{c}\text { Al-doped } \\
\mathrm{ZnO}\end{array}$ & $\begin{array}{c}\text { Al-doped } \\
\mathrm{ZnO}\end{array}$ & $\begin{array}{c}\text { Al-doped } \\
\mathrm{ZnO}\end{array}$ \\
\hline Al percentage & 0 & 0.1 & 0.2 & 0.5 & 1 \\
$\begin{array}{l}\text { Bandgap before } \\
\text { laser irradiation, eV }\end{array}$ & 3.139 & 3.170 & 3.173 & 3.185 & 3.210 \\
$\begin{array}{l}\text { Bandgap after laser } \\
\text { irradiation, eV }\end{array}$ & 3.10 & 2.96 & 3.10 & 3.08 & 3.0 \\
\hline
\end{tabular}



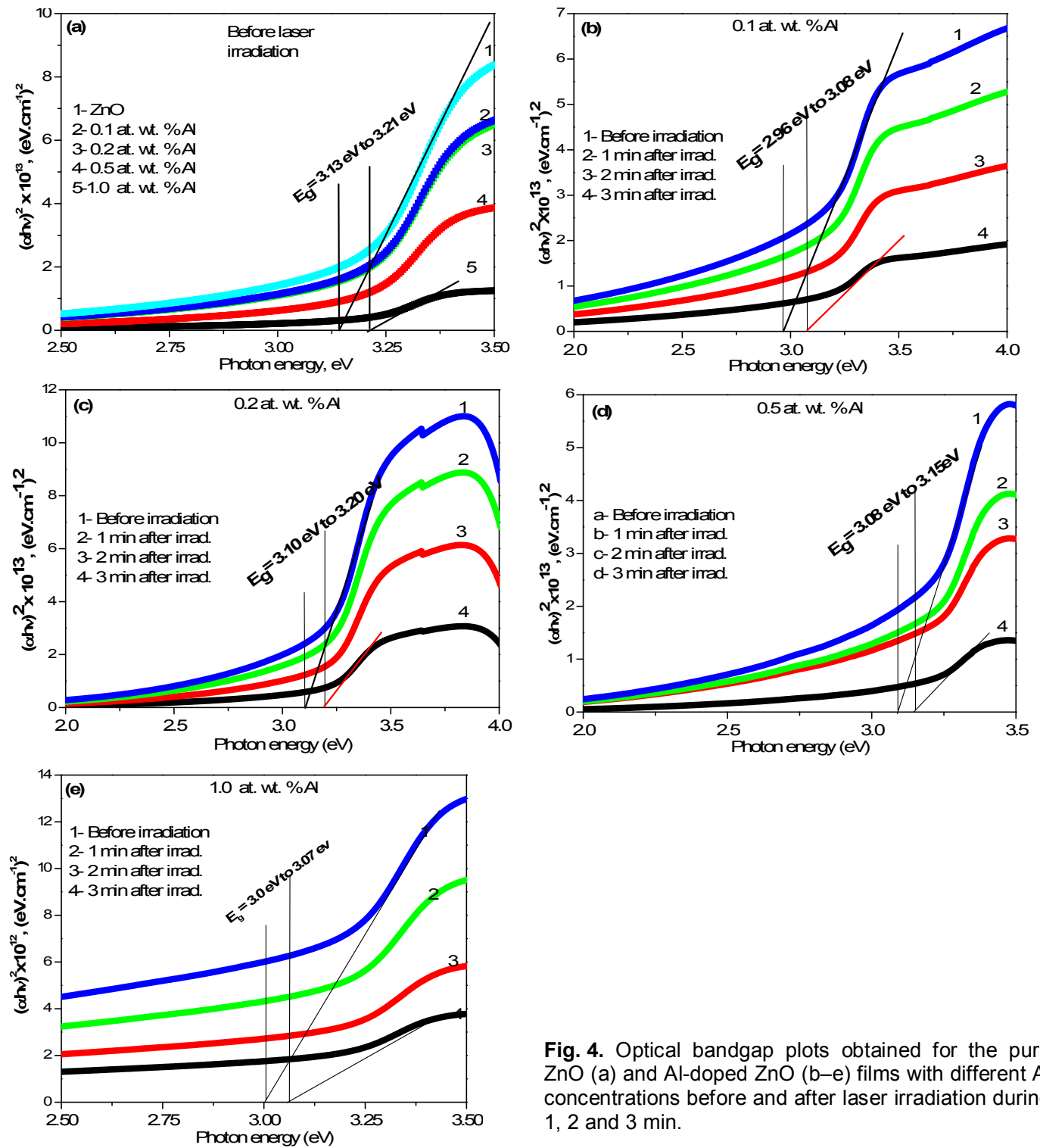

Fig. 4. Optical bandgap plots obtained for the pure $\mathrm{ZnO}$ (a) and Al-doped $\mathrm{ZnO}$ (b-e) films with different $\mathrm{Al}$ concentrations before and after laser irradiation during 1,2 and $3 \mathrm{~min}$.

The bandgaps calculated for different Al-doped $\mathrm{ZnO}$ films irradiated during different times are depicted in Fig. 4b-e. It is evident that the bandgap for Al-doped $\mathrm{ZnO}$ slightly decreases with increasing $\mathrm{Al}$ concentration. The overall effect of laser irradiation on the bandgap is significant, as seen from the values listed in Table 3 . The changes detected in the bandgap of the Al-doped $\mathrm{ZnO}$ films under laser treatment can be attributed to small changes in the crystallite sizes, the changes in the thickness of the films owing to confinement effect [42] and heating of the samples.

\subsection{IR absorption}

To investigate the molecular structure of our samples under conditions of fast laser irradiation, we have employed the Fourier transform IR spectroscopy technique. The IR absorption spectra for pure $\mathrm{ZnO}$ and $\mathrm{Al}$-doped $\mathrm{ZnO}$ under different irradiation conditions are depicted in Fig. 5. Doping of $\mathrm{ZnO}$ with $\mathrm{Al}$ influences the relative IR intensity. This intensity decreases with increasing $\mathrm{Al}$ content. The absorption values around 3570, 2916, 2852 and $2107 \mathrm{~cm}^{-1}$ (i.e., 
shoulders) are slightly reduced due to laser irradiation. For instance, the two bands located near 2852 and $2916 \mathrm{~cm}^{-1}$ for $\mathrm{ZnO}$ decrease noticeably with increasing irradiation time. These two weak peaks are due to $\mathrm{C}-\mathrm{H}$ stretching vibrations of alkane groups [43]. There is small influence of $\mathrm{Al}$ on the peaks of $\mathrm{ZnO}$. The observed peaks correlate well with the frequencies of $\mathrm{C}-\mathrm{H}_{2}$ symmetric stretch $\left(2855 \mathrm{~cm}^{-1}\right), \mathrm{C}-\mathrm{H}_{2}$ asymmetric stretch $\left(2926 \mathrm{~cm}^{-1}\right)$ and $\mathrm{C}-\mathrm{H}_{3}$ asymmetric stretch $\left(2962+10 \mathrm{~cm}^{-1}\right)$ of saturated hydrocarbons (see Ref. [44]).
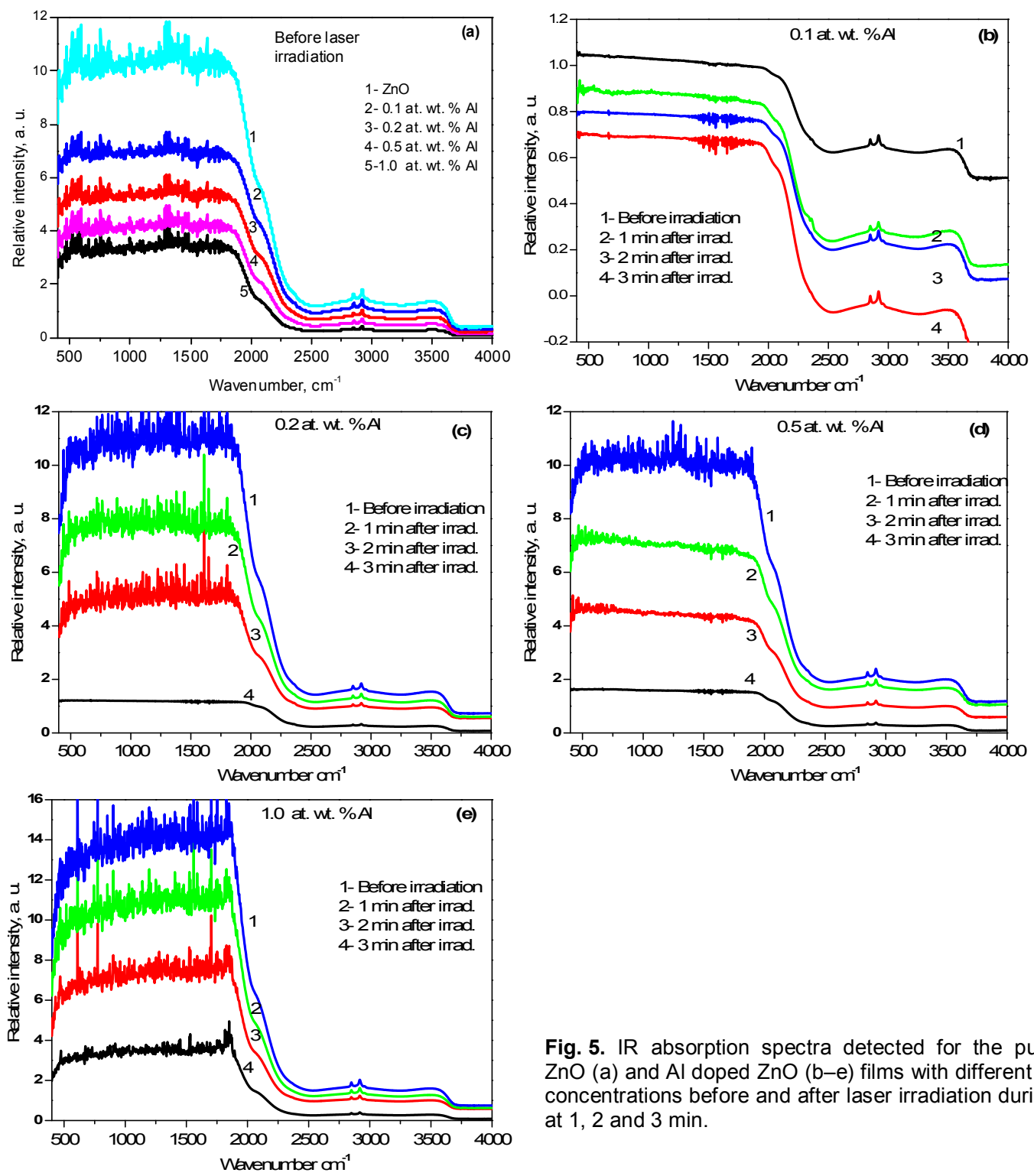

Fig. 5. IR absorption spectra detected for the pure $\mathrm{ZnO}$ (a) and $\mathrm{Al}$ doped $\mathrm{ZnO}(\mathrm{b}-\mathrm{e})$ films with different $\mathrm{Al}$ concentrations before and after laser irradiation during at 1,2 and $3 \mathrm{~min}$.

A decrease in the intensities of both the XRD and the IR absorption observed for the Aldoped $\mathrm{ZnO}$ thin films under laser irradiation can be caused by deterioration of crystalline quality. In general, reduced intensities of the XRD peaks and the IR absorption bands can also be due to decreased absorption of irradiated layers, although the laser energy is too low to induce ablation. Therefore, we assume that the above effect is associated with changing nanocrystal sizes and changing structure. Unfortunately, we could not perform the microscopic studies or measure the 
film thicknesses in the present work. The reason is difficulties that appear when handling our samples after laser treatment. The above studies for the fresh samples will be a subject of our further work.

\subsection{PL}

The PL properties of the pure $\mathrm{ZnO}$ and $\mathrm{Al}$-doped $\mathrm{ZnO}$ films are depicted in Fig. 6. Here a comparison with the emission spectra (see Fig. 5b-e) would be fruitful. The PL peak for pure $\mathrm{ZnO}$ is observed at $381 \mathrm{~nm}$. This peak corresponds to a near-band edge UV emission typical for the nanostructured $\mathrm{ZnO}$ films. It is normally observed at approximately $3.26 \mathrm{eV}$ and represents a result of direct recombination of photogenerated charge carriers or excitons [44]. This PL peak is influenced when $\mathrm{ZnO}$ becomes doped with Al. As clearly seen from Fig. 6, the intensity of the peak decreases with increasing Al percentage, and it has a slight red shift. The intensity of the peak
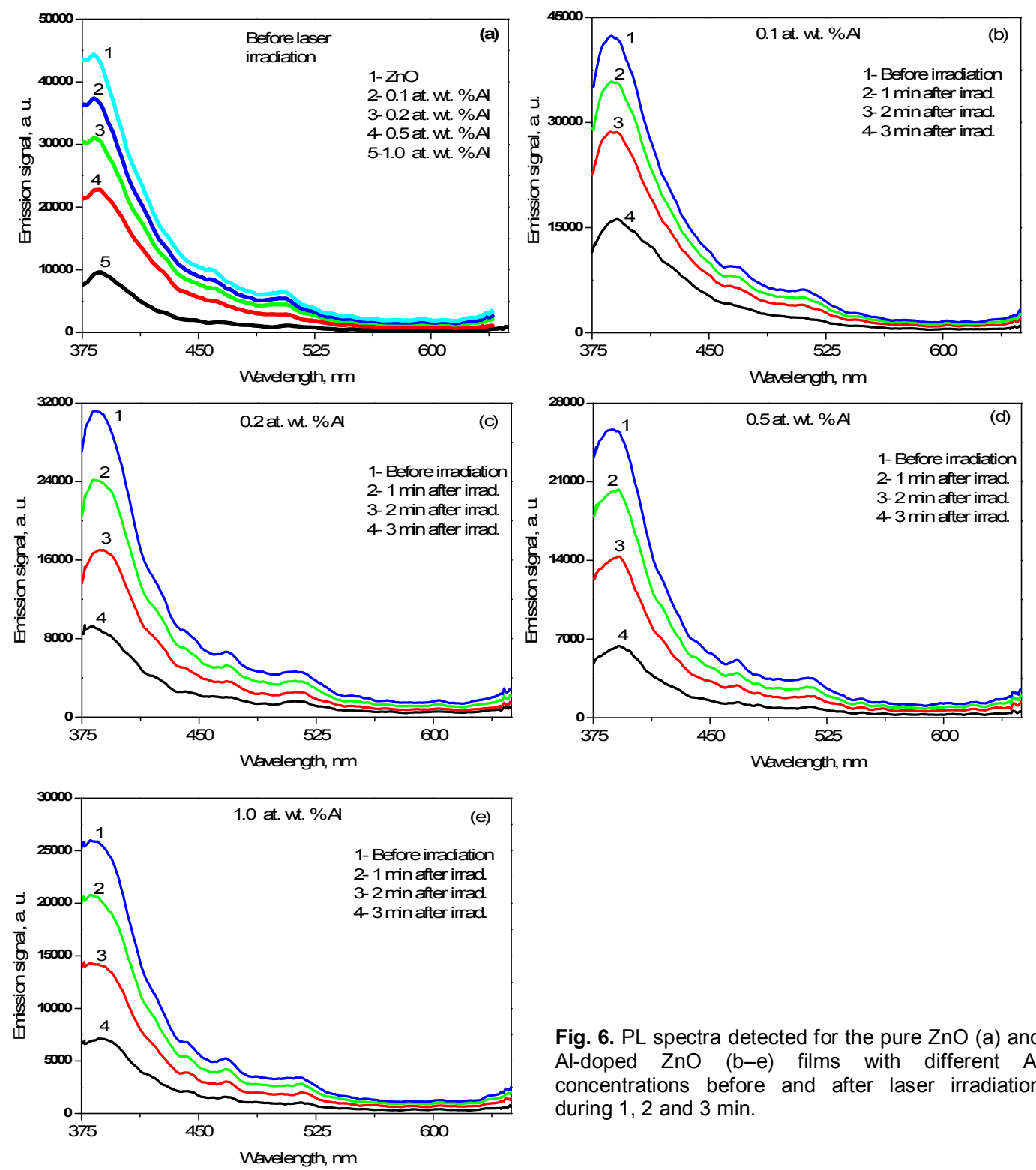

Fig. 6. PL spectra detected for the pure $\mathrm{ZnO}(\mathrm{a})$ and Al-doped $\mathrm{ZnO}$ (b-e) films with different Al concentrations before and after laser irradiation during 1,2 and $3 \mathrm{~min}$.

Ukr. J. Phys. Opt. 2020, Volume 21, Issue 3 
Table 4. Emission peaks detected for the pure $\mathrm{ZnO}$ and $\mathrm{Al}$-doped $\mathrm{ZnO}$ thin films before and after 3 min-long laser irradiation.

\begin{tabular}{lccccc}
\hline Sample (thin film) & $\begin{array}{c}\text { Pure nano- } \\
\text { structured } \mathrm{ZnO}\end{array}$ & $\begin{array}{c}\text { Al-doped } \\
\mathrm{ZnO}\end{array}$ & $\begin{array}{c}\text { Al-doped } \\
\mathrm{ZnO}\end{array}$ & $\begin{array}{c}\text { Al-doped } \\
\mathrm{ZnO}\end{array}$ & $\begin{array}{c}\text { Al-doped } \\
\mathrm{ZnO}\end{array}$ \\
\hline Al percentage & 0 & 0.1 & 0.2 & 0.5 & 1 \\
$\begin{array}{l}\text { Emission wave- } \\
\text { length before laser }\end{array}$ & 381 & 382 & 382 & 385 & 388 \\
$\begin{array}{l}\text { irradiation, nm } \\
\begin{array}{l}\text { Emission wave- } \\
\text { length after laser } \\
\text { irradiation, nm }\end{array}\end{array}$ & 383 & 391 & 383 & 393 & 389 \\
\hline
\end{tabular}

decreases with increasing laser exposure time. Then a slight red shift also occurs, as seen from Table 4. Note that the intensities for the Al-doped $\mathrm{ZnO}$ films shown in Fig. 5 decrease significantly with increasing irradiation time. This indicates that the PL intensity of the nanostructured $\mathrm{ZnO}$ with $\mathrm{Al}$ is affected significantly by the laser energy. It means that the surface of the nanostructured Al-doped $\mathrm{ZnO}$ films is degraded by the laser irradiation. Since the PL property of $\mathrm{ZnO}$ depends on the conditions of crystallization of the films, the crystal quality becomes deteriorated in case of longer irradiation times. Slight shifts occurring in the emission peaks with increasing irradiation time are also evident from Table 4 .

Our observations prove that both the $\mathrm{Al}$ doping and the irradiation performed using the $355 \mathrm{~nm}$ picosecond laser affect the behaviour of emission in the nanostructured $\mathrm{ZnO}$ films. A similar behaviour has earlier been observed in the work by Aohi et al. [22], where the UV emission intensity of single-crystalline $\mathrm{ZnO}$ wafers decreases under irradiation by a $\mathrm{KrF}$ excimer laser. This has been attributed to deterioration in crystallinity on $\mathrm{ZnO}$ surface. Wang et al. [23] have also reported a similar effect for Mg-doped GaN thin films irradiated by a laser. Here the effect can be tentatively attributed to surface re-crystallization under proper laser conditions.

It is interesting that the $\mathrm{UV}$ emission intensity is linked with the resistivity, since $\mathrm{O}$ vacancies and $\mathrm{Zn}$ interstitials in pure $\mathrm{ZnO}$ play a role of main carriers and donors that determine the resistivity of samples. It is also known that the photon energy of high-power laser sources can break $\mathrm{Zn}-\mathrm{O}$ bonds [24].

The effects revealed in the present study for the UV emission in nanostructured Al-doped $\mathrm{ZnO}$ films can correspond to laser influence. Indeed, it is evident from the data reported in Ref. [45] that the PL intensity of the $\mathrm{ZnO}$ films decreases with increasing laser irradiation energy. In general, the visible emission depends mainly on the native defects in $\mathrm{ZnO}$ films. The type and the concentration of defects determine respectively the locations and the intensities of the emission bands. Therefore, the laser irradiation has the effect both on the intensity and the energy location of the emission.

\section{Conclusion}

In the present work we have studied the influence of laser irradiation on the nanostructured Aldoped $\mathrm{ZnO}$ films. The irradiation effect has been studied for the cases of different irradiation times. XRD, optical absorption, optical bandgap, IR absorption and PL have been systematically studied under the same conditions. We have demonstrated that the optical properties of $\mathrm{ZnO}$ are influenced by both the $\mathrm{Al}$ doping and the laser irradiation. Our results reveal that the XRD intensity and the bandgap of Al-doped $\mathrm{ZnO}$ decrease with increasing $\mathrm{Al}$ percentage and laser 
irradiation time. The absorption peak intensity is slightly changed when $\mathrm{ZnO}$ is doped with $\mathrm{Al}$. The degree of decrease in the absorbance is different for different doping concentrations and irradiation times. The bandgap of Al-doped $\mathrm{ZnO}$ decreases slightly and a blue shift occurs as the $\mathrm{Al}$ concentration increases.

The IR absorption for Al-doped $\mathrm{ZnO}$ is also influenced by the $\mathrm{Al}$ percentage and the laser irradiation time. The PL intensity decays with increasing Al doping, with a slight red shift. One can conclude that the irradiation of the surface of nanostructured Al-doped $\mathrm{ZnO}$ films by the short laser pulses deteriorates the structure and changes the sizes of nanocrystals. Though the energy fluence is well below the ablation level in the present experiments, it would be useful to understand the microscopic behaviour related to the film thickness. The work in this direction is in progress.

\section{Acknowledgement}

The authors are thankful to Laser and Spectroscopy Lab, King Abdullah Institute for Nanotechnology, King Saud University, for providing the base for experimental work.

\section{References}

1. Naik G V, Kim J and Boltasseva A, 2011. Oxides and nitrides as alternative plasmonic materials in the optical range. Opt. Mater. Exp. 1: 1090-1099.

2. Franzen S, 2008. Surface plasmon polaritons and screened plasma absorption in indium tin oxide compared to silver and gold. J. Phys. Chem. C. 112: 6027-6032.

3. Ginley D S and Bright C. 2000. Transparent conducting oxides. MRS Bulletin. 25: 15-18.

4. Minami T, 2000. New n-type transparent conducting oxides. MRS Bulletin. 25: 38-44.

5. Triboulet $\mathrm{R}$ and Perrière J, 2003. Epitaxial growth of ZnO films. Prog. Cryst. Growth Charact. Mater. 47: 65-138.

6. Shaoqiang C, Jian Z, Xiao F, Xiaohua W, Laiqiang L, Yanling S, Qingsong X, Chang W, Jianzhong $\mathrm{Z}$ and Ziqiang Z, 2005. Nanocrystalline $\mathrm{ZnO}$ thin films on porous silicon/silicon substrates obtained by sol-gel technique. Appl. Surf. Sci. 241: 384-391.

7. Jiao S J, Zhang Z Z, Lu M Y, Shen D Z, Yao B, Zhang J Z, Li B H, Zhao D X, Fan X W and Tang $\mathrm{Z}$. K, 2006. $\mathrm{ZnO}$ p-n junction light-emitting diodes fabricated on sapphire substrates. Appl. Phys. Lett. 88: 031911-3.

8. Priyanka Jood, Rutvik J Mehta, Yanliang Zhang, Germanas Peleckis, Xiaolin Wang, Richard W. Siegel, Theo Borca-Tasciuc, Shi Xue Dou, and Ganpati Ramanath, 2011. Al-doped zinc oxide nanocomposites with enhanced thermoelectric properties. Nano Lett. 11: 4337-4342.

9. Bhosle V, Prater J T, Yang F, Burk D, Forrest S R and Narayan J, 2007. Gallium-doped zinc oxide films as transparent electrodes for organic solar cell applications. J. Appl. Phys. 102: 15.

10. Venkatesh P S, Ramakrishnan V and Jeganathan K, 2012. Vertically aligned indium doped zinc oxide nanorods for the application of nanostructured anodes by radio frequency magnetron sputtering. Cryst. Eng. Comm. 14: 3907-3914.

11. Lin J M, Zhang Y Z, Ye Z Z, Gu XQ, Pan XH, Yang YF, Lu JG, He HP, Zhao BH, 2009. Nbdoped $\mathrm{ZnO}$ transparent conducting films fabricated by pulsed laser deposition. Appl. Surf. Sci. 255: 6460-6463.

12. Verma A, Khan F, Kar D, Chakravarty B C, Singh S N and Husain M. 2010. Sol-gel derived aluminum doped zinc oxide for application as anti-reflection coating in terrestrial silicon solar cells. Thin Solid Films. 518: 2649-2653.

Ukr. J. Phys. Opt. 2020, Volume 21, Issue 3 
13. Serier H, Gaudon M and Menetrier M, 2009. Al-doped $\mathrm{ZnO}$ powdered materials, Al Solubility limit and IR absorption properties. Solid State Sci. 11: 1192-1197.

14. Du S F, Tian Y J, Liu H D, Liu J and Chen Y F, 2006. Calcination effects on the properties of gallium-doped zinc oxide powders. J. Amer. Ceram. Soc. 89: 2440-2443.

15. Zhang, W H, Zhang W D and Zhou J F, 2009. Solvent thermal synthesis and gas-sensing properties of Fe-doped ZnO. J. Mater. Sci. 45: 209-241.

16. Khan M A, Kumar M S, Khan M N, Ahamed M and Al Dwayyan A S, 2014. Microstructure and blue shift in optical band gap of nanocrystalline $\mathrm{Al}_{\mathrm{x}} \mathrm{Zn}_{1-\mathrm{x}} \mathrm{O}$ thin films. J. Lumin. 155: 275281.

17. Ji Y L and Jiang Y J, 2006. Increasing the electrical conductivity of poly(vinylidene fluoride) by $\mathrm{KrF}$ excimer laser irradiation. Appl. Phys. Lett. 89: 221103-3.

18. Chang L, Jiang Y J and Ji L, 2007. Improvement of the electrical and ferro-magnetic properties in $\mathrm{La}_{0.67} \mathrm{Ca}{ }_{0.33} \mathrm{MnO}_{3}$ thin film irradiated by $\mathrm{CO}_{2}$ laser. Appl. Phys. Lett. 90: 082505.

19. Overschelde O V, Guisbiers G and Wantelet M, 2009. Nanocrystallization of anatase or rutile $\mathrm{TiO}_{2}$ by laser treatment. J Phys. Chem C. 113: 15343-15345.

20. Hui L, Yaoquan T, Lin X, Fang, B, Luo D and Laaksonen A, 2010. Effects of laser irradiation on the structure and optical properties of $\mathrm{ZnO}$ thin films. Mater. Lett. 64: 2072-2075.

21. Shan F K and Yu Y S, 2004. Band gap energy of pure and Al-doped ZnO thin films. J. Eur. Ceram. Soc. 24: 1869-1872.

22. Aohi T, Hatanka Y and Look D C, 2000. ZnO diode fabricated by excimer-laser doping. Appl. Phys. Lett. 76: 3257-2.

23. Wang X C, Lim G C, Liu W, Soh C B and Chua S J, 2005. Effects of $248 \mathrm{~nm}$ excimer laser irradiation on the properties of Mg-doped GaN. Appl. Surf. Sci. 252: 2071.

24. Zhao $\mathrm{Y}$ and Jiang $\mathrm{Y}, 2008$. Effect of $\mathrm{KrF}$ excimer laser irradiation on the properties of $\mathrm{ZnO}$ thin films. J. Appl. Phys. 103: 114903-3.

25. Nie M, Zhao Y and Zeng Y, 2014. Effects of annealing and laser irradiation on optical and electrical properties of $\mathrm{ZnO}$ thin films. J. Laser Appl. 26: 022005-6.

26. Oh M S, Kim S H, Hwang D K, Park S J and Seong T Y, 2005. Formation of low resistance nonalloyed $\mathrm{Ti} / \mathrm{Au}$ ohmic contacts to $\mathrm{n}-\mathrm{Type} \mathrm{ZnO}$ by $\mathrm{KrF}$ excimer laser irradiation. ElectroChem. Solid-State Lett. 8: G317-G319.

27. Oh M S, Hwang D K, Lim J H, Choi Y S and Park S J, 2007. Improvement of Pt Schottky contacts to n-type $\mathrm{ZnO}$ by $\mathrm{KrF}$ excimer laser irradiation. Appl. Phys. Lett. 91: 042109-3.

28. Xu Q, Hong R D, Huang H L, Zhang Z F, Zhang M K, Chen X P and Wu Z Y, 2013. Laser annealing effect on optical and electrical properties of $\mathrm{Al}$ doped $\mathrm{ZnO}$ films. Opt. \& Laser Techn. 45: 513-517.

29. Hou Y and Jayatissa A H, 2014. Effect of laser irradiation on gas sensing properties of sol-gel derived nanocrystalline Al-doped $\mathrm{ZnO}$ thin films. Thin Solid Films. 562: 585-591.

30. Scorticati D, Illiberi A, Bor T, Eijt S, Schut H, Reomer G, Gunnewiek M K, Lenferink A, Kniknie B, Joy R M, Dorenkamper M, de Lange D, Otto C, Borsa D, Soppe W and Veld A H, 2015. Thermal annealing using ultra-short laser pulses to improve the electrical properties of Al:ZnO. Acta Mater. 98: 327-335.

31. Tang F L, Wong M K, Fung J C, Chang C S and Lee S T, 2008. Transparent conducting aluminum doped zinc oxide thin film prepared by sol-gel process followed by laser irradiation treatment. 517: 891-895. 
32. Akdağ A, Budak H F, Efe M Y A, Büyükaydın M, Can M, Turgut G and Sönmez E, 2016. Structural and morphological properties of $\mathrm{Al}$ doped $\mathrm{ZnO}$ nanoparticles. J. Phys: Conf. Ser. 707: 012020-6.

33. Benzarouk H, Drici A A, Mekhnache M, Amara A A, Guerioune M and Bernede J C, 2012. Effect of different dopant elements ( $\mathrm{Al}, \mathrm{Mg}$ and $\mathrm{Ni}$ ) on microstructural, optical and electrochemical properties of $\mathrm{ZnO}$ thin films deposited by spray pyrolysis (SP). Superlattices Microstruct. 52: 594-604.

34. Alver U, Kilinc T, Bacaksiz E, Nezir S and Mutlu I H, 2007. Temperature dependence of ZnO rods produced by ultrasonic spray pyrolysis method. Mater. Chem. Phys. 106: 227-230.

35. Muiva C M, Sathiaraj T S and Maabong K, 2011. Effect of doping concentration on the properties of aluminium doped zinc oxide thin films prepared by spray pyrolysis for transparent electrode applications. Ceram. Int. 37: 555-560.

36. Ilican S, Caglar Y and Caglar M, 2008. Preparation and characterization of $\mathrm{ZnO}$ thin films deposited by sol-gel spin coating method. J. Optoelectron. Adv. Mater. 10: 2578-2583.

37. Zhang W Y, He D K, Liu Z Z, Sun L J and Fu Z X, 2010. Preparation of transparent conducting Al-doped $\mathrm{ZnO}$ thin films by single source chemical vapour deposition. J. Optoelectron. Adv. Mater - Rapid Commun. 4 (11): 1651-1654.

38. Burstein E, 1954. Anomalous optical absorption limit in InSb. Phys. Rev. 25: 632-633.

39. Sernelius B E, Berggren K F, Jin Z C, Hamburg I and Granqvist C G, 1988. Band-gap tailoring of $\mathrm{ZnO}$ by means of heavy Al doping. Phys. Rev. B. 37: 10244-10248.

40. Maeng W J, Lee J, Lee J H, Chung K B and Park J S, 2011. Studies on optical, structural and electrical properties of atomic layer deposited $\mathrm{Al}$-doped $\mathrm{ZnO}$ thin films with various $\mathrm{Al}$ concentrations and deposition temperatures. J. Phys. D: Appl. Phys. 44: 445305-7.

41. Al-Ghamdi A A, Al-Hartomy O A, El Okr, M, Nawar A M, El-Gazzar S, El Tantawy F and Yakuphanoglu F, 2014. Semiconducting properties of Al doped ZnO thin films. Spectrochim. Acta A: Molec. Biomolec. Spectr. 131: 512-517.

42. Srinatha N, No Y S, Kamble V B, Chakravarty S, Suriyamurthy N, Angadi B, Umarjif A M and Choib W K, 2016. Effect of RF power on the structural, optical and gas sensing properties of RF-sputtered Al doped ZnO thin films. RSC Adv. 6: 9779-9788.

43. Djelloul A, Aida M S and Bougdira J, 2010. Photoluminescence, FTIR and X-ray diffraction studies on undoped and $\mathrm{Al}$-doped $\mathrm{ZnO}$ thin films grown on polycrystalline $\alpha$-alumina substrates by ultrasonic spray pyrolysis. J. Lumin. 130: 2113-2117.

44. Nickel N H and Fleischer K, 2003. Hydrogen local vibrational modes in zinc oxide. Phys. Rev. Lett. 90: 197402-4.

45. Kim Y S and Tai W P, 2007. Electrical and optical properties of Al-doped ZnO thin films by sol-gel process. Appl. Surf. Sci. 253: 4911-4916.

Khan M. N., Almohammedi A. and Farooq W. A. 2020. Effect of picosecond-laser irradiation on the properties of nanostructured aluminium-doped zinc oxide thin films. Ukr.J.Phys.Opt. 21: $126-140$. doi: $10.3116 / 16091833 / 21 / 3 / 126 / 2020$

Анотація. Тонкі плівки наноструктурованого оксиду циику, легованого алюмінієм різної концентрації, синтезовано на скляних підкладках за допомогою процесу золь-гель із покриттям, одержаним за методом иентрифугування. Вилив пікосекундного лазерного опромінення на ці тонкі плівки вивчено різними оптичними методиками. Їхні структурні та оптичні властивості з'ясовано шляхом досліджень рентгенівської дифракиії, видимого

Ukr. J. Phys. Opt. 2020, Volume 21, Issue 3 
та інфрачервоного спектрів поглинання, а також фотолюмінесценції. Величину оптичної щуілини обчислено за методом Таука. Виявлено незначні зміни у відносній інтенсивності рентгенівської дифракиї та розширення ліній як результат лазерного опромінення, яке викликає певний розлад кристалічної будови. Відносні інтенсивності спектрів поглинання та випромінювання зменшуються зі зростанням відсоткового складу алюмінію та часу лазерної експозиції. Величина ицього зменшення залежить від концентрачії легуючої речовини. Крім того, явище емісї виявляє незначний червоний зсув. Розмір нанокристалів також змінюється зі змінами відсотку алюмінію та часу експозиції. Пониження відносної інтенсивності, згадане вище, пояснюється зміною розмірів нанокристалів та структури поверхневого шару. 